\title{
The Role of Microfinance Sector In Up Lifting The Performance Of Small Scale Industry And Empowering Women In Pakistan
}

\author{
Rummana Zaheer \\ \& \\ Bilal Hussain \\ Department of Economics \\ University of Karachi
}

\begin{abstract}
An endeavor has been made in this paper to ascertain the reasons behind the bleak performance of the economy of Pakistan in spite of the fact that the country possesses cheaper labor as compared to many countries of the world. With a big portion of our labor force - comprising of women has been neglected even from unemployment alleviation planning. The data used in this study was available from December 2007 to September 2010. Looking up to neighboring China and its economic progress as the most populated country of the world brought its population in the economic fold, Pakistani government also needs to come up with some similar strategy but related to its own society norms. Pakistan could also bring a big part of its population by strengthening microfinance sector and subsequently small sector of the country. There is great scope in the microfinance industry in Pakistan provided that the government objectively patronizes the activities of the microfinance banks and institutions.
\end{abstract}

\section{تلخيصِ مقالْ}

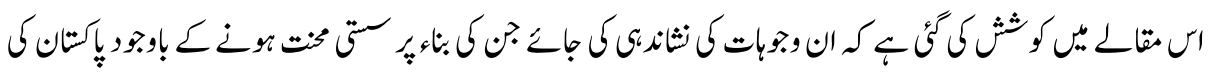

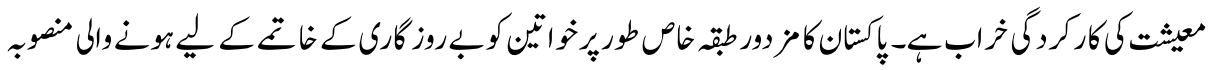

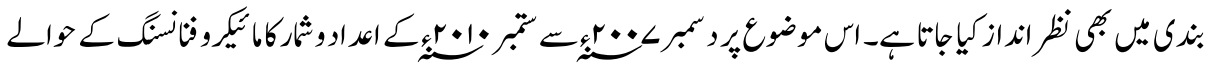

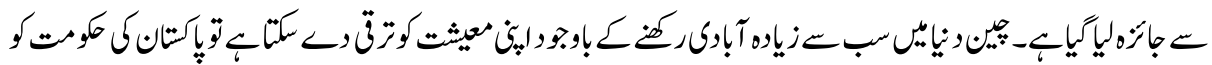

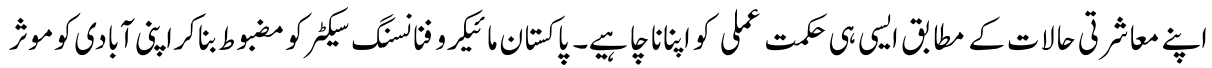

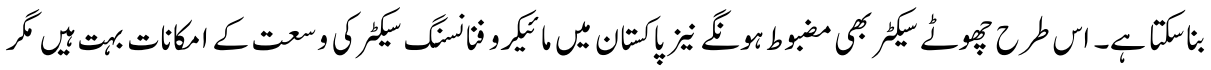

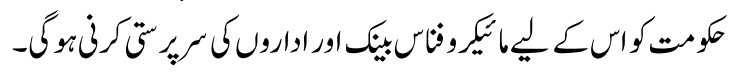

\section{Introduction}

In this paper, an effort has been made to highlight the reasons due to which financial institution in Pakistan have failed to reach small scale sector effectively, in spite 
precedents set by Nobel Laureate Dr. Yonus in neighboring Bangladesh, formerly a part of Pakistan and has roughly faced similar problems as that of Pakistan, with both falling in the vast basket of 'developing countries'.

Dr. Younus' brainchild Grameen Bank, have been targeting poor work force especially women in Bangladesh to empower them to earn their living with their small scale enterprises.

To understand how the microfinance enterprises has a capability to alleviate poverty, an in depth analysis must be done to see how much the population are involved in different sectors of the country.

Three main factors, which are technological change, agricultural or industrial inputs and technical efficiency contributes in both agricultural and industrial growth. The change in technology is an outcome of research and efforts made for development, while the technical efficiency, which comes by using new technology, could both be adopted and more prudently be used if information, better infrastructure and funds are made available to farmer's or other cottage industry worker's so that they could enhance managerial capabilities. The better mix of inputs for better productivity must be backed by funds at the disposal of small scale sector (Iqbal, Ahmed, Abbas 2003).

The costs incurred during the transaction made in lending to small scale sector would be compared with that of credit costs extended to large or medium scale farmers (landlords) and Industrialists.

Transaction cost consists of the administration cost, which are incurred by processing, delivering, and administering of loans. This cost of administration rises as the volume of loans reduces, the time period shortens, and services of accounting expand so that the large number of small-scale borrowers could be served. Meanwhile there is another cost of risks and defaults involved in lending credit.

In assessing cost of credit, seldom attention has been given to the transaction costs of lending due to lack of availability of relevant information (Saito, Villanueva 1981). Transaction cost consists of the administration cost, which are incurred by processing, delivering, and administering of loans.

Formal lenders and financial institution, are biased and tend to extend loans to large landowners and industrialists, probably with better collateral. Large landowners represent only 4 percent of rural population, however, they manages to get 42 percent of formal loans. Small scale farmers, who represent 69 percent of the rural population, receive only 23 percent of formal credit (Khandker, Faruqee 2001). 
Aleem (1990) noted in his study that many credit surveys in developing countries have found that normally non-institutional lenders, such as moneylenders, landlords or traders, those people who have money at disposable to lent, charge much higher interest as compared to rates charged by institutional lenders such as banks.

The efficient development outcomes, that could also be considered equitable, rely on the degree of how much financial institution put constraints on low-wealth producers in their access to credit (Barham, et.al. 1996).

Khandker and Pitt (1996) surveyed households in Bangladesh to ascertain the impacts of microfinance on different outcomes. They tried to know whether microfinance effects get saturated or crowded out over time. They explored a declining long-term positive effect of microfinance which could be a result of the villages getting saturated from microfinance loans.

Although Bangladesh's microfinance organizations have made good progress but the transaction costs they incurred were high for maintaining results to maintain credit discipline among borrowers and the programs mostly relied on donors (Khandker 1996; Khalily etal 2000; Morduch 1999; Yaron 1994).

The microfinance helps the poor mainly, however chances are little to observe equal benefits enjoyed by everyone (Hossain 1988). Many studies conducted in and out of Bangladesh suggests that microfinance operations has been effective in the country (Hashemi et. al. 1996).

Even in the $21^{\text {st }}$ century, Pakistan's major problem is still poverty. According to World Bank's income standard for defining a poverty baseline is $\$ 1$ per day of purchasing power parity income on a 1993 base. Considering this standard, approximately 31 percent of the population of Pakistan comes under the poverty line in 1996 as reported in World Development Indicators for 2001 (Mellor 2001). So it is believed that the government and other social groups should focus on poor and under-privileged classes and invest and open new arenas for these classes to earn respectable livelihood.

Khandker (2005) proposed that the access to funds, made available by microfinance programs, could contribute reducing poverty, especially helping to empower women folks, at the village level. So bringing them in a large portion of labor force in economic fold of the country, microfinance also helps local economy in the process.

Ledgerwood (1998) argued that the sustainability of MFBs and MFIs financially is essential as opportunity cost would be high in the absence of microfinance institutions. 
The trade-off between the commercial objectives and social aims has been debated widely. But the cost of this trade off could be minimized if growth strategy is adopted. This strategy focuses on bettering efficiency and productivity (Craig and Cheryl, 2006).

It is believed that the efficiency of the microfinance industry in the country - both urban and rural areas, especially women, would help in bringing the unprivileged class in the effectively in the economic circle.

\section{Microfinance Reach in Pakistan}

The Microfinance industry in Pakistan is yet to makes its impact in Pakistan by reaching millions of underprivileged people, who could use financial services to up lift their living standards and subsequently be productive.

According to SBP, Pakistan's financial institution's penetration in Pakistan has one of the lowest level in the World with more than half - 56 percent of the adult population being completely excluded. Another $32 \%$ has been informally served.

In spite of the government support, State Bank and other donors, the microfinance industry has tapped only a small part of potential market with total current borrowers being roughly two million.

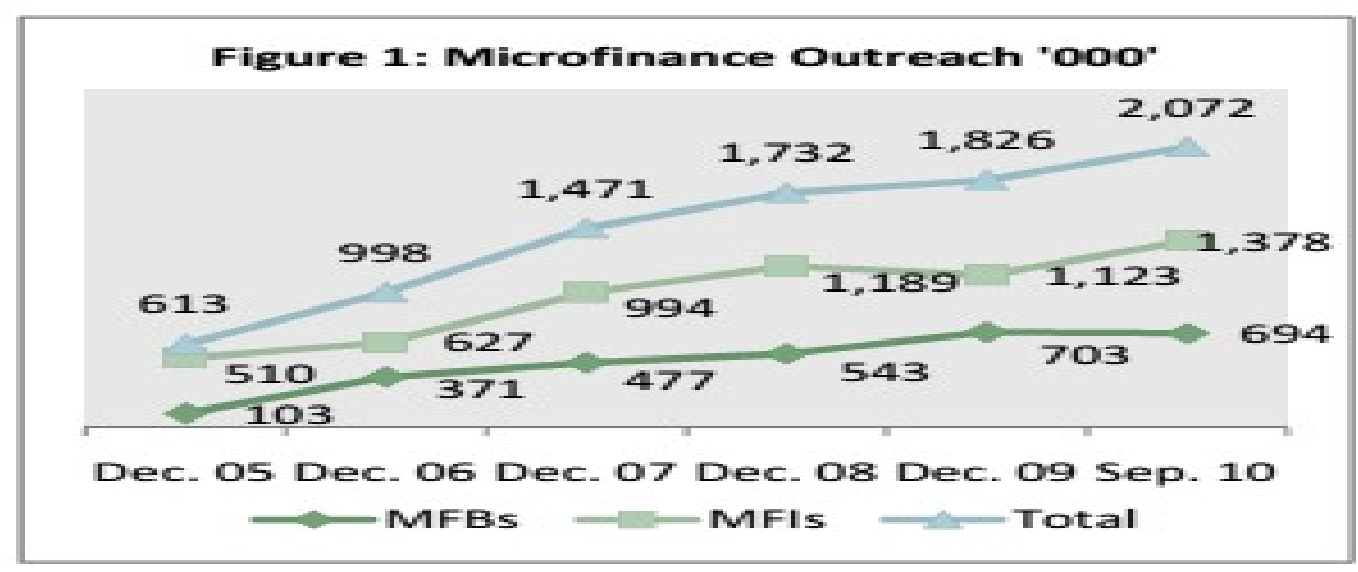

Source: Strategic Framework for Sustainable Microfinance in Pakistan (State Bank of Pakistan Microfinance Department 2011)

\section{Comparison with International Benchmarks}

When the microfinance sector in Pakistan is compared with global large and medium institution, it was found out that the deposits were low, Operational Self-Sufficiency (OSS) has also been low at $94 \%$. 
However, the risk of the gross loan portfolio as compared with international players was quite low, which may encourage the sector to expand.

\section{Key Indicators for Comparision - 2009}

\begin{tabular}{|lccccc|}
\hline & $\begin{array}{c}\text { Gross Loan } \\
\text { Portfolio/ } \\
\text { Total Assets } \\
(\%)\end{array}$ & $\begin{array}{c}\text { Deposits to } \\
\text { Total Assets } \\
(\%)\end{array}$ & $\begin{array}{c}\text { Operational } \\
\text { Self-Sufficiency } \\
(\%)\end{array}$ & $\begin{array}{c}\text { Average Loan } \\
\text { Balance per } \\
\text { borrower/GNI per } \\
\text { capita (\%) }\end{array}$ & $\begin{array}{c}\text { Portfolio at } \\
\text { Risk>30 days } \\
(\%)\end{array}$ \\
\hline $\begin{array}{l}\text { Microfinance Sector in } \\
\text { Pakistan }\end{array}$ & $\mathbf{5 7}$ & $\mathbf{2 1}$ & 94 & 14 & 1.9 \\
\hline $\begin{array}{l}\text { Large Institutions } \\
\text { (Global) }\end{array}$ & 75.4 & 27.8 & 118 & 59.3 & 4.4 \\
\hline $\begin{array}{l}\text { Medium Institutions } \\
\text { (Global) }\end{array}$ & 74.8 & 20.6 & 109 & 74.2 & 5.5 \\
\hline
\end{tabular}

Source: Strategic Framework for Sustainable Microfinance in Pakistan (State Bank of Pakistan Microfinance Department 2011)

The gross loan portfolio to total assets is low when compared with benchmarks for microfinance sector of Pakistan. The industry need to extend loans in order to increase the income to cover the total assets.

\section{Key Indicators Comparison with Global Leading Institutions -2009}

\begin{tabular}{|c|c|c|c|c|c|}
\hline & $\begin{array}{c}\text { Gross Loan } \\
\text { Portfolio/Total } \\
\text { Assets (\%) }\end{array}$ & $\begin{array}{l}\text { Deposits to } \\
\text { Total Assets } \\
\text { (\%) }\end{array}$ & $\begin{array}{c}\text { Operational } \\
\text { Self-Sufficiency } \\
(\%)\end{array}$ & $\begin{array}{c}\text { Average Loan } \\
\text { Balance per } \\
\text { borrower/GNI per } \\
\text { capita }(\%)\end{array}$ & $\begin{array}{c}\text { Portfolio } \\
\text { at Risk>30 } \\
\text { days (\%) }\end{array}$ \\
\hline $\begin{array}{l}\text { Microfinance Sector in } \\
\text { Pakistan }\end{array}$ & 57 & 21 & 94 & 14 & 1.9 \\
\hline CARD Bank, Philippines & 76.98 & 64.29 & 108.92 & 6.06 & 1.87 \\
\hline ASA, Bangladesh & 91.65 & $31.82^{*}$ & 136.92 & 16.87 & 4.44 \\
\hline BRAC, Bangladesh ${ }^{7}$ & 66.57 & $23.46^{*}$ & 105.27 & 21.79 & 7.69 \\
\hline K-Rep, Kenya & 75.67 & 55.00 & 76.82 & 166.56 & 22.33 \\
\hline BancoSol, Bolivia & 77.16 & 68.63 & 104.66 & 212.73 & 0.95 \\
\hline
\end{tabular}

Source: Strategic Framework for Sustainable Microfinance in Pakistan (State Bank of Pakistan Microfinance Department 2011)

However, the microfinance industry has slowly been spreading its reach as the borrowers have nearly doubled from the December 2007 to September 2010. The loans extended to the borrowers have increased more than twice, showing that the average loan taken by per borrower has also increased. The microfinance banks and institutions have slowly started trusting its borrowers. 


\section{Micro Finance Industry Indicators}

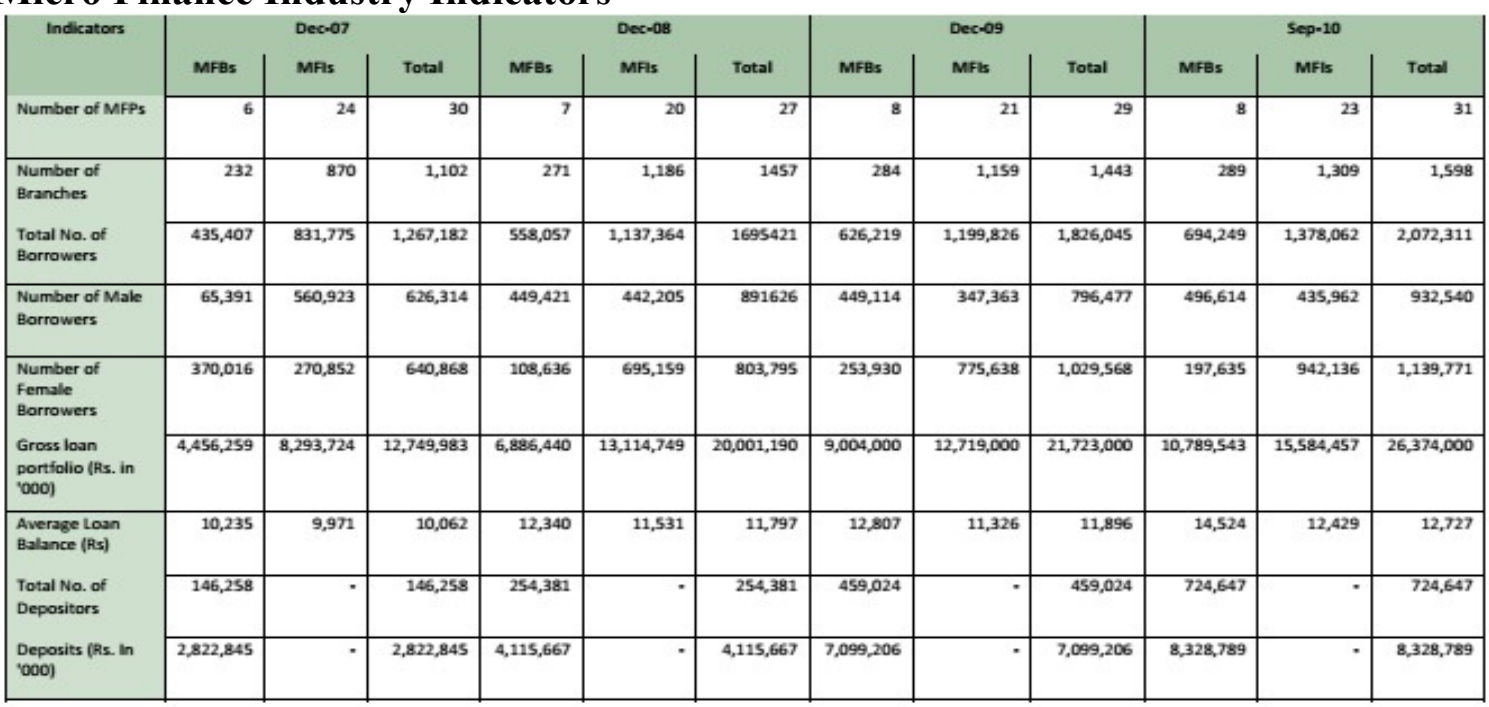

Source: Strategic Framework for Sustainable Microfinance in Pakistan (State Bank of Pakistan Microfinance Department 2011)

Performance Indicators of Microfinance Banks in Pakistan, As of End September 2010

\begin{tabular}{|c|c|c|c|c|c|c|c|c|c|}
\hline MFBs & Branches & Borrowers & $\begin{array}{l}\text { Advances } \\
\text { (PKR 000) }\end{array}$ & $\begin{array}{l}\text { Deposits } \\
\text { (PKR 000) }\end{array}$ & $\begin{array}{c}\text { Assets } \\
\text { (PKR 000) }\end{array}$ & $\begin{array}{l}\text { Borrowing } \\
\text { (PKR 000) }\end{array}$ & $\begin{array}{c}\text { Equity } \\
\text { (PKR 000) }\end{array}$ & $\begin{array}{l}\text { NPL } \\
\text { (\%) }\end{array}$ & OSS (\%)* \\
\hline KBL & 113 & 352,743 & $4,129,635$ & 198,782 & $6,620,837$ & $4,019,160$ & $2,230,746$ & $1.96 \%$ & $118.90 \%$ \\
\hline FMFB & 83 & 204,301 & $3,181,759$ & $5,291,011$ & $6,051,049$ & - & 523,428 & $4.97 \%$ & $103.10 \%$ \\
\hline Tameer & 40 & 104,726 & $2,835,506$ & $2,296,135$ & $4,136,529$ & 513,379 & $1,089,686$ & $0.92 \%$ & $85.50 \%$ \\
\hline Kashf & 27 & 18,142 & 449,178 & 474,050 & $1,271,234$ & 300,000 & 402,065 & $3.65 \%$ & $52.2 \%$ \\
\hline Pak Oman & 17 & 8,113 & 109,214 & 28,125 & 719,455 & - & 677,340 & $9.09 \%$ & $90.9 \%$ \\
\hline Network & 5 & 6,224 & 84,251 & 40,686 & 278,122 & - & 230,747 & $38.51 \%$ & $101.01 \%$ \\
\hline Rozgar & 4 & 14 & 726 & 23,221 & 122,826 & - & 96,963 & $64.46 \%$ & $45.60 \%$ \\
\hline Total & 289 & 694,263 & $10,790,269$ & $8,352,010$ & $19,200,052$ & $4,832,539$ & $5,250,975$ & $3.00 \%$ & $99.2 \%$ \\
\hline
\end{tabular}

Source: Strategic Framework for Sustainable Microfinance in Pakistan (State Bank of Pakistan Microfinance Department 2011)

\section{Conclusions}

Microfinance industry has a direct positive effect in lifting the performance of the small scale industry of Pakistan. However, the industry lacks luster for the financiers as they couldn't charge its borrowers - who are from humble background (lacks collateral), with higher interest rates than the prevailing normal rates in spite of the fact that the costs 
incurred are higher, as it would irritate government and civil societies to grill the apparent exploiting behavior.

Government agencies especially State Bank of Pakistan has already noticed this uninterested attitude and has started giving subsidies to the microfinance industry. However, government also needs to strengthen its own infrastructure so as to give ample chance for micro-financiers to reach to the remote rural areas - where bigger pie of the population dwells.

The government has to play a bigger role in making the microfinance industry more attractive but it should not directly involve itself as the former trends show immense cases of corruption and political affinity towards borrowers and eventually losses to the microfinance entities - making the industry unattractive and therefore discouraging the potential investors.

The government should involve itself in opening new horizons for its underprivileged through teaching technical expertise and then recommend the potential borrowers to the privately owned microfinance institutions.

\section{References}

Aleem, I (1990). Imperfect Information, Screening, and the Costs of Informal Lending: A Study of a Rural Credit Market in Pakistan. The World Bank Review, Vol. 4, NO. 3: pp, 329-349.

Barham, B.L., Boucher, S. \& Carter, M.R. (1996). Credit Constraints, Credit Unions and Small Scale Producers in Guatemala. World Development, Vol. 24, No. 5, pp, 793-806.

Iqbal, M., Ahmad, M. \& Abbas, K (2003). The Impact of Institutional Credit on Agricultural Production in Pakistan. The Pakistan Development Review, 42: 4 Part II, pp, 469-485.

Khandker, S.R. \& Faruqee, R.R. (2001). The Impact of Farm Credit in Pakistan. World Development Research Group Rural Development. Policy Research Working Paper 2653.

Khandker, S.R. (2005). Microfinance and Poverty: Evidence Using Panel Data from Bangladesh. The World Bank Economic Review Vol.19, No.2. 
Mellor J.W. (2001). Employment Multipliers from Agricultural Growth and Poverty Reduction. The Pakistan Development Review 40: 4 Part I, pp, 371-400.

Saito, A.K. \& Vilianueva D.P. Transaction Costs of Credit to the Small-Scale Sector in the Philippines (1981). Economic Development and Cultural Change, vol. 29, no. $3, \mathrm{pp}, 631-40$.

\section{Appendix}

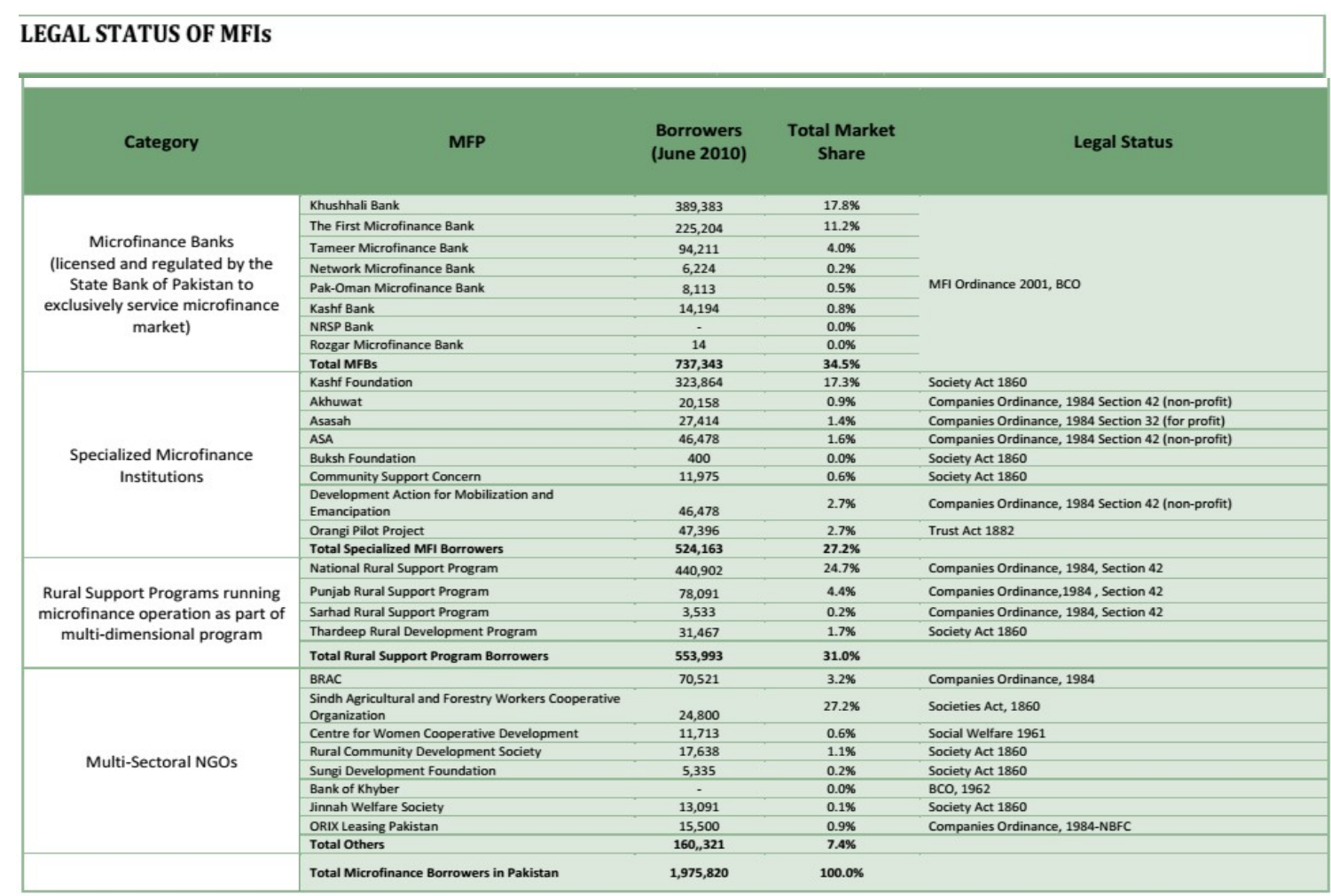

Source: Strategic Framework for Sustainable Microfinance in Pakistan (State Bank of Pakistan Microfinance Department 2011)

Dr. Rummana Zaheer is Assistant Professor in the Department of Economics, University of Karachi.

Bilal Hussain is M.Phil Student, University of Karachi. 